\title{
JURNAL TEKNOLOGI
}

http://jurnalftijayabaya.ac.id/index.php/JTek

DOI: https://doi.org/10.31479/jtek.v1i8.66

\section{Implementasi Algoritma Nä̈ve Bayes Classifier Dan Confusion Matrix Dalam Analisis Sentimen Terhadap Pelayanan Transportasi Umum Selama Pandemi Covid-19 Pada Media Sosial Twitter}

\author{
${ }^{1}$ Riskania, ${ }^{2}$ Farid Thalib \\ ${ }^{1}$ Jurusan Sistem Informasi, Fakultas Ilmu Komputer dan Teknologi Informasi Universitas Gunadarma, \\ Jl.Margonda Raya No. 100, Depok 16424, Jawa Barat \\ ${ }^{2}$ Pusat Studi Sistem Sensor dan Teknik Pengukuran, Universitas Gunadarma, Jl. Margonda Raya No. 100, \\ Depok 16424, Jawa Barat \\ *) Corresponding author: farid@ staff.gunadarma.ac.id
}

(Received: $31 \mathrm{Oct} \cdot$ Revised: $20 \mathrm{Nov} \cdot$ Accepted: $28 \mathrm{Nov})$

\begin{abstract}
The COVID-19 pandemic has an impact on various aspects. One of those affected is public transportation. The decrease in passenger numbers was caused by policies issued to support government efforts to prevent the spread of the Covid-19 virus. This policy triggers passenger opinion regarding the services provided. This opinion can be expressed through various media, one of which is Twitter. The passenger's opinion on Twitter about public transportation services can be positive or negative. Passenger opinion can be used as data in conducting sentiment analysis. This data can be obtained using crawling techniques. Sentiment analysis was carried out to determine the trend of passenger opinions regarding public transportation services during the Covid-19 pandemic. The data obtained are as many as 650 data that are labeled positive and negative. The data is divided into training data of $60 \%$ or 390 data, and test data of $40 \%$ or 260 data. This data can be used to make a machine learning model using the Naïve Bayes Classifier algorithm. The formation of this machine learning model has an accuracy rate of $83.8 \%$, which results from testing the test data using a confusion matrix.
\end{abstract}

ABSTRAK

Pandemi COVID-19 memberikan dampak diberbagai aspek. Salah satu yang terkena dampak adalah transportasi umum. Penurunan jumlah penumpang disebabkan oleh kebijakan yang dikeluarkan untuk mendukung upaya pemerintah dalam pencegahan penyebaran virus Covid-19. Kebijakan ini memicu opini penumpang mengenai pelayanan yang diberikan. Opini tersebut dapat dituangkan melalui berbagai media salah satunya Twitter. Opini penumpang yang tertuang didalam Twitter mengenai pelayanan transportasi umum dapat bersifat positif atau pun negatif. Opini penumpang dapat digunakan sebagai data dalam melakukan analisis sentimen, data ini dapat diperoleh dengan menggunakan teknik crawling. Analisis sentimen dilakukan untuk mengetahui kecenderungan opini penumpang mengenai pelayanan transportasi umum selama pandemi Covid-19. Data yang didapatkan sebanyak 650 data yang diberikan label positif dan negatif. Data dibagi menjadi data latih sebanyak $60 \%$ atau 390 data, dan data uji $40 \%$ atau 260 data. Data ini dapat digunakan untuk proses pembuatan model mechine learning menggunakan Metode algoritma Nä̈ve Bayes Classifier . Hasil pembentukan model mechine learning ini memiliki tingkat akurasi sebesar $83,8 \%$ yang dihasilkan dari pengujian data uji dengan menggunakan confusion matrix.

Keywords : Confusion Matrix, COVID-19, Nä̈ve Bayes Classifier, Public Transportation, Sentiment Analysis. 


\section{PENDAHULUAN}

Suatu perusahaan memiliki beberapa perangkat atau fasilitas yang berhubungan dengan listrik, khususnya pada ruang lingkup Utility perusahaan. Banyak perangkat yang berhubungan dengan kondisi On dan Off seperti lampu penerangan, AC, Motor Kompresor, Kipas dan lain sebagainya. Perangkat tersebut dapat berfungsi ketika dihidupkan. Tetapi ada suatu kelemahan yaitu ketika alat tersebut tidak dipergunakan dan beroperasi secara terus menerus. Tentu saja hal ini berkaitan erat dengan konsumsi daya listrik yang digunakan. Semakin lama alat tersebut beroperasi, semakin besar pula konsumsi daya listrik yang digunakan.

Contoh yang seringkali terjadi adalah ketika lampu penerangan yang lupa dimatikan, padahal kondisi sudah siang. Untuk kelas perusahaan jumlah lampu yang digunakan tidaklah sedikit, semakin banyak lampu yang dinyalakan, semakin banyak pula konsumsi daya yang digunakan. Contoh yang lain adalah AC atau kipas angin dalam suatu ruangan, tidak sedikit yang lupa untuk mematikan peralatan tersebut [1]. Beberapa contoh yang lain adalah kompresor yang digunakan untuk energi angin ke semua mesin di perusahaan yang masih dalam kondisi On ketika sudah akhir produksi atau menjelang libur [2].

Beberapa poin di atas adalah contoh permasalahan yang sering terjadi di suatu perusahaan. Faktor man power dan metode sangat berpengaruh terhadap semua proses di atas. Dapat disimpulkan penggunaan daya listrik akan berlebih dan berbanding lurus dengan biaya yang harus dikeluarkan, seiring dengan pemakaian yang diluar kebutuhan dari fasilitas utility perusahaan tersebut.

Penelitian ini merupakan pengembangan dari beberapa penelitian sebelumnya yaitu Penggunaan PLC Sebagai Pengontrol Peralatan Building Automatis, PLC digunakan untuk mengontrol peralatan Building Automation System (BAS) diantaranya yaitu Air Conditioner (AC), lampu dan stop kontak di suatu ruangan yang disesuaikan pengaturannya melalui setting waktu dalam pemograman yang telah tersedia di PLC itu sendiri. Khusus untuk AC dan pengontrolannya menggunakan sensor Inframerah. Dengan adanya PLC sebagai pengontrol utama seluruh sistem di dalam gedung dapat bekerja secara otomatis dan manual serta mengupayakan agar mempermudah dan memperingan pekerjaan manusia di area gedung [3]. Jika dilihat dari poin di atas, penelitian tersebut menggunakan PLC sebagai alat untuk melakukan otomasi sistem yaitu dengan beberapa intruksi-intruksi internal dari PLC itu sendiri. Untuk visualisasinya menggunakan sebuah kit atau alat dengan beberapa sensor yang berfungsi untuk mendeteksi beberapa masukan yang sudah ditentukan. Penelitian selanjutnya yaitu Rancang Bangun Sistem Kendali Otomatis Silo Dengan Metode Sortasi Berdasarkan Jenis Kemasan Produk Menggunakan HMI-PLC, membahas tentang PLC Outseal yang digunakan untuk mengontrol jalannya proses produksi. PLC yang digunakan pada penelitian ini adalah Outseal PLC Shield yang diprogram menggunakan aplikasi Outseal Studio, dan HMI yang digunakan adalah LCD 20x4 yang dikontrol oleh Arduino Mega 2560 yang diprogram menggunakan aplikasi Arduino IDE. PLC digunakan sebagai kontrol utama sistem, sedangkan Arduino digunakan untuk mengontrol komponen yang lain [4].

Outseal PLC adalah PLC berbasis arduino seperti nampak pada Gambar 1. Outseal adalah nama perusahaan dan juga merek dagang dari pengembang teknologi otomasi asal Indonesia, yang bergerak di bidang pengembangan teknologi instrumentasi dan otomasi. Teknologi yang telah dikembangkan oleh Outseal diantaranya adalah PLC (Programmable Logic Controller) dan HMI (Human Machine Interface) [5]. 


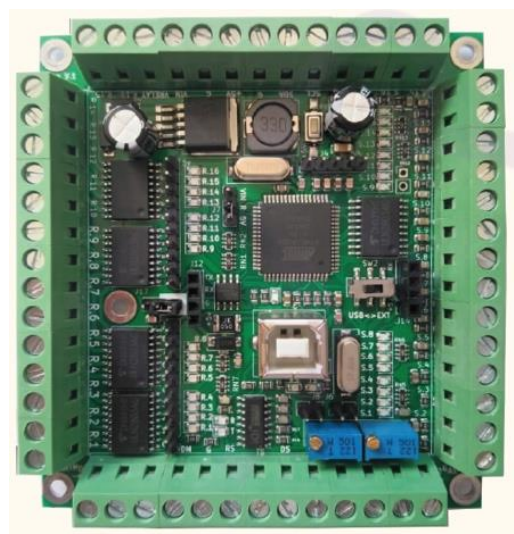

Gambar 1. Outseal PLC Mega V.1 [6]

HMI Modbus adalah salah satu aplikasi android yang digunakan untuk melakukan pemantauan dan kontrol pada peralatan atau perangkat elektronik dengan menggunakan Modbus seperti layaknya Scada. HMI Modbus dirancang untuk komunikasi antara perangkat berbasis Android dengan perangkat apapun yang mendukung protokol komunikasi Modbus[7]. HMI Modbus dapat digunakan sebagai pengganti panel operator sederhana untuk membaca dan menulis register sesuai dengan alamat yang sudah disesuaikan antara program pada aplikasi dan alamat pada perangkat lunak yang akan dikomunikasikan. Untuk koneksinya dapat menggunakan Bluetooth atau melalui WiFi. Untuk penelitian ini akan menggunakan Internet atau WiFi sebagai koneksinya. Aplikasi dapat diunduh secara gratis di Google Play Store [8].

TTL-WiFi dirancang dan dikembangkan berdasarkan modul WiFi ESP-M2 dari perusahaan Shenzhen Doctors of Intelligence \& Technology Co., Ltd., yang mengekstraksi pin TTL, EN, STATE, dan lainnya. TTL-WiFi sudah terintegrasi dengan firmware transmisi transparan serial yang diprogram oleh perusahaan (SZdoit), yang dapat melakukan pengiriman data secara real-time. Modul ini dapat menggantikan perangkat WiFi serial kabel [9].

Tujuan dari penelitian ini adalah untuk membuat suatu alat menggunakan aplikasi android, untuk memantau dan mengontrol data penggunaan daya dengan membandingan daya pada saat beban penuh dan pada saat beban tidak dipakai, memanfaatkan teknologi Outseal PLC karya anak bangsa yang saat ini tengah banyak diminati oleh beberapa engineer terkait dengan beberapa keuntungan yang didapatkan dengan menggunakan PLC tersebut.

\section{METODE PENELITIAN}

Penelitian yang dilakukan menggunakan metode eksperimental dimana serangkaian perancangan serta percobaan dilakukan secara langsung berdasarkan kajian teoritis dari berbagai literatur sehingga dapat menghasilkan penelitian yang diharapkan, seperti yang diilustrasikan dalam diagram pada Gambar 2. 


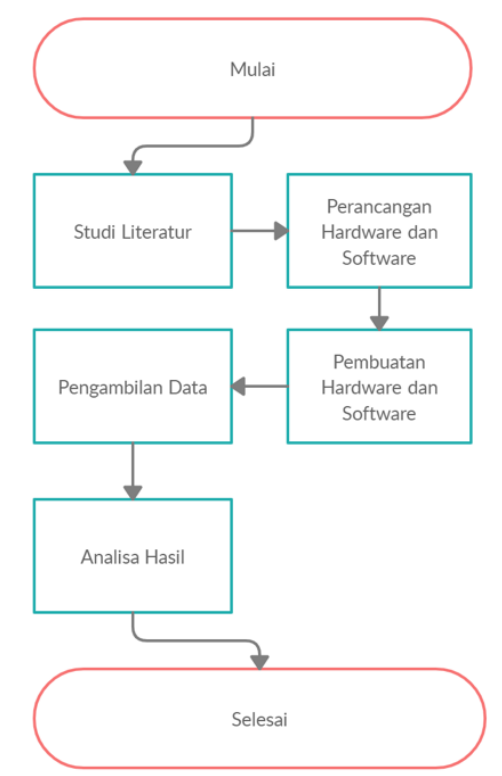

Gambar 2. Diagram Alur Penelitian

Pada Gambar 3. mengilustrasikan wiring diagram dari Outseal PLC.

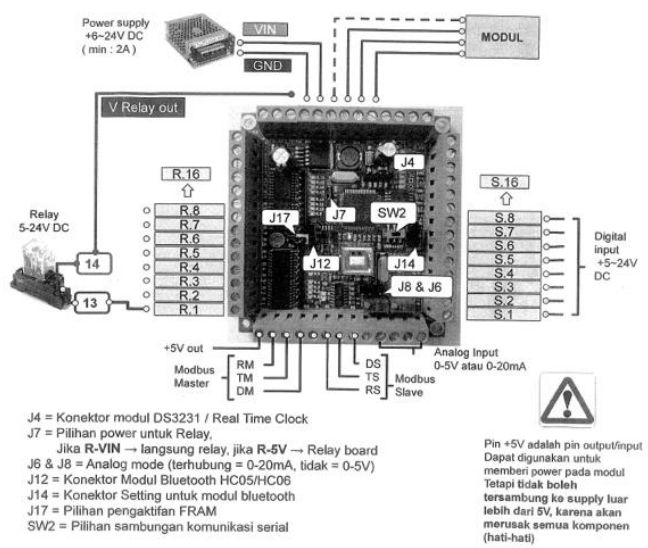

Gambar 3. Wiring Diagram Outseal PLC Mega V.1 [10]

Desain dari pembuatan alat ini dibagi menjadi dua bagian, yaitu desain perangkat keras, dan desain perangkat lunak. Desain perangkat keras meliputi komponen-komponen apa saja yang akan dipakai dan wiring diagram yang digunakan. Untuk desain dari perangkat keras dibagi menjadi 3 bagian yaitu Input, Proses dan Output. Gambar 4. menujukkan blok diagram cara kerja alat.

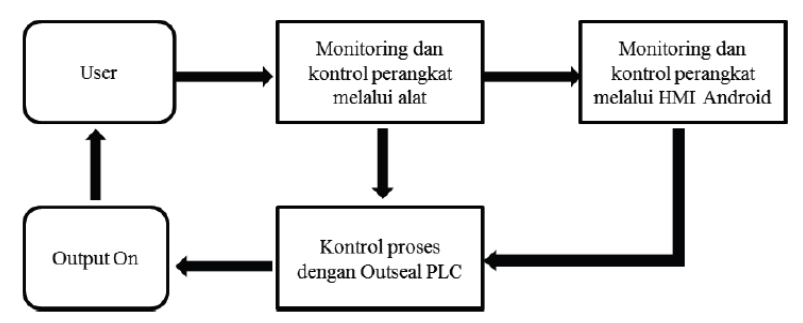

Gambar 4. Blok Diagram Sistem Monitoring dan Kontrol 
Dapat dilihat pada blok diagram diatas, user dapat melakukan monitoring dan kontrol melalui internal perangkat maupun pada smartphone atau android, kemudian akan di proses melalui Outseal PLC dan hasilnya akan ditampilkan kembali kepada user. Pada Gambar 5 adalah desain dari perangkat keras yang digunakan:

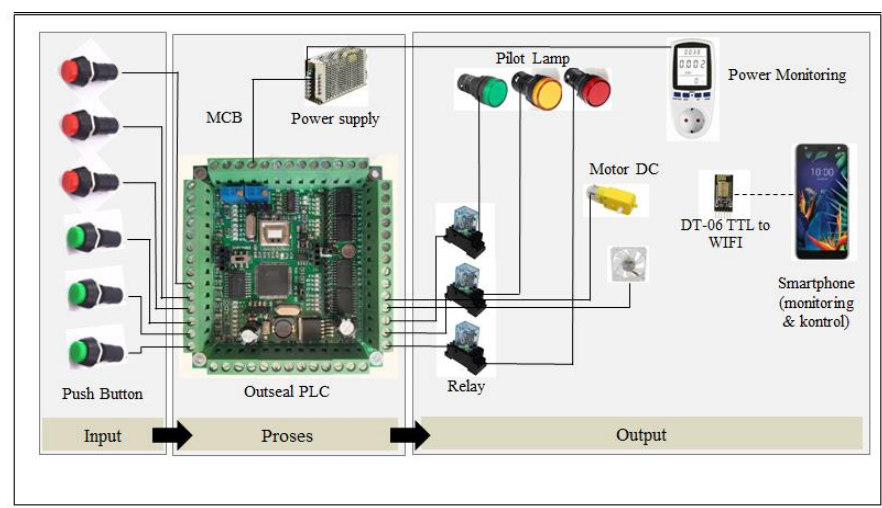

Gambar 5. Desain Perangkat Keras

(Sumber: Hasil Penelitian)

Dari desain yang ditampilkan di atas, komponen yang akan digunakan ditampilkan pada Tabel 1.

Tabel 1. Komponen Input - Proses - Output

\begin{tabular}{|c|c|c|}
\hline Nama Proses & Nama komponen & Jumlah \\
\hline \multirow{3}{*}{ Input } & Push Button (hijau) & $3 \mathrm{pcs}$ \\
\cline { 2 - 3 } & Push Button (merah) & $3 \mathrm{pcs}$ \\
\hline \multirow{4}{*}{ Proses } & Outseal PLC & $1 \mathrm{pc}$ \\
\cline { 2 - 3 } & Modul DT-06 & $1 \mathrm{pc}$ \\
\cline { 2 - 3 } & Power Supply 24 V DC & $1 \mathrm{pc}$ \\
\hline \multirow{5}{*}{ Output } & Relay Omron MY2N 24 V DC & $3 \mathrm{pcs}$ \\
\cline { 2 - 3 } & Pilot Lamp 220 V AC (Hijau) & $1 \mathrm{pcs}$ \\
\cline { 2 - 3 } & Pilot Lamp 220 V AC (Orange) & $1 \mathrm{pcs}$ \\
\cline { 2 - 3 } & Pilot Lamp 220 V AC (Merah) & $1 \mathrm{pcs}$ \\
\cline { 2 - 3 } & Fan Kotak 5 V DC & $1 \mathrm{pcs}$ \\
\cline { 2 - 3 } & Motor DC & $1 \mathrm{pcs}$ \\
\cline { 2 - 3 } & Taffware Watt Meter & $1 \mathrm{pcs}$ \\
\cline { 2 - 3 } & &
\end{tabular}




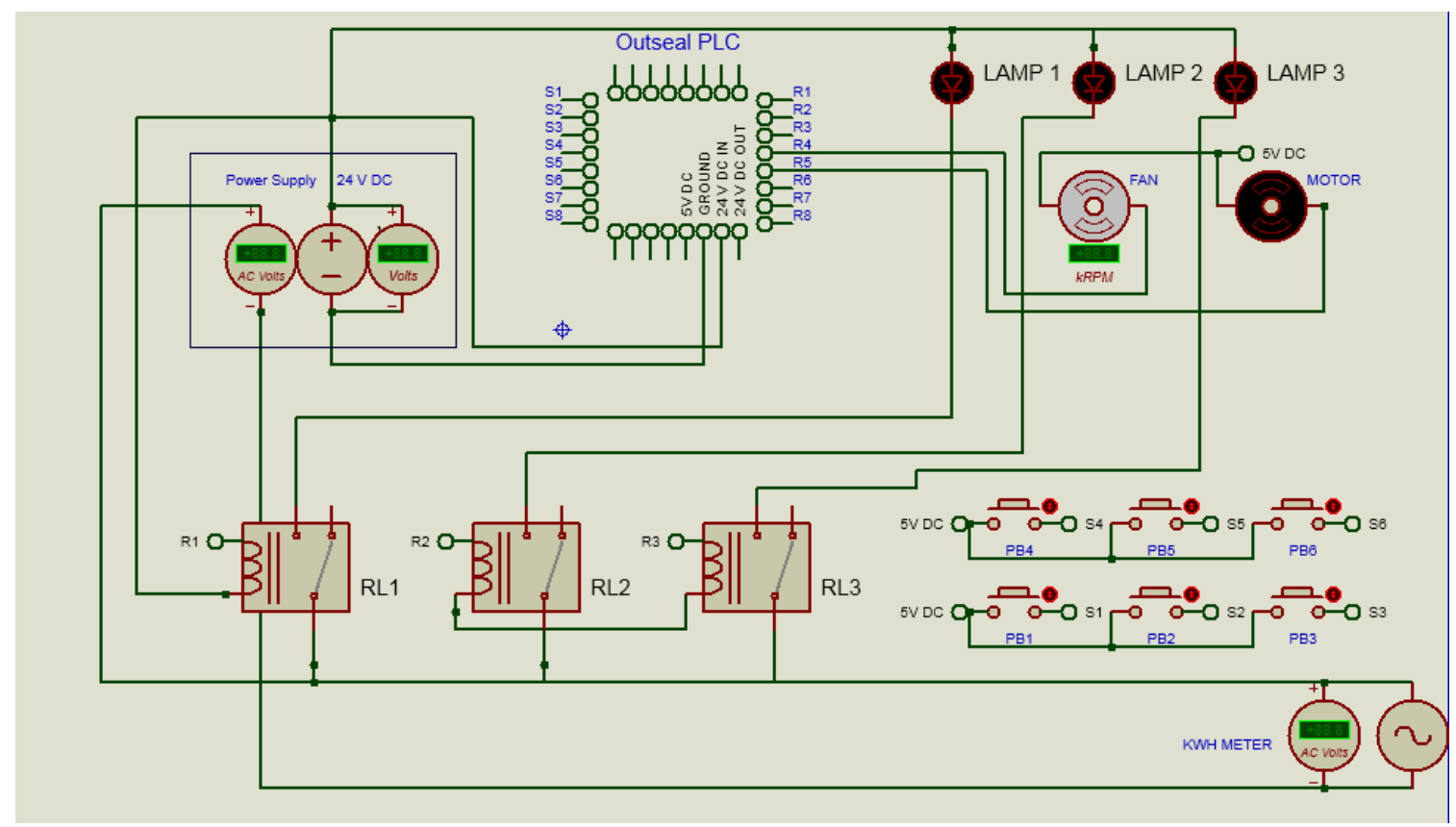

Gambar 6. Wiring Diagram Alat

(Sumber: Hasil Penelitian)

Pada wiring diagram Gambar 6 terdapat power supply $24 \mathrm{~V}$ DC digunakan untuk memberikan tegangan pada Outseal PLC, dan selanjutnya untuk kebutuhan power relay, fan dan motor DC. Untuk pilot lamp menggunakan power $220 \mathrm{~V} \mathrm{AC}$, dan terdapat KWH Meter untuk melihat besarnya konsumsi daya yang digunakan pada alat tersebut. Gambar 7 adalah hasil proses perakitan.
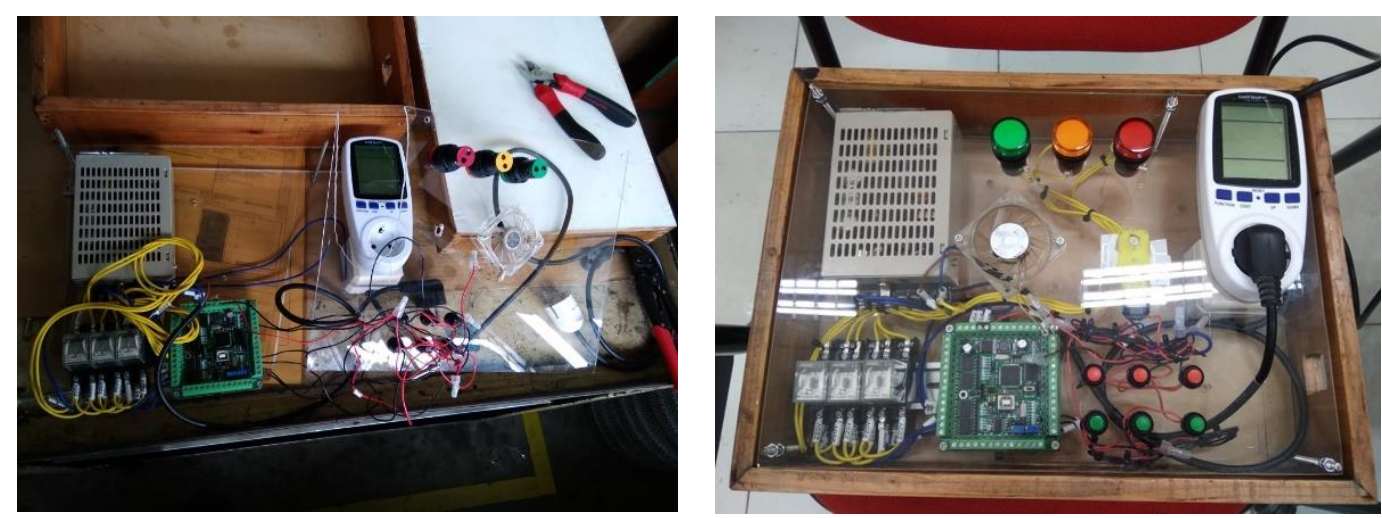

Gambar 7. Hasil Proses Perakitan

(Sumber: Hasil Penelitian)

Setelah proses perakitan perangkat keras diselesaikan (Gambar 7), tahap selanjutnya adalah desain perangkat lunak atau program. Outseal PLC menggunakan perangkat lunak Outseal Studio yang dapat diunduh melalui website Outseal. Gambar 8 adalah gambaran dari program yang digunakan. 


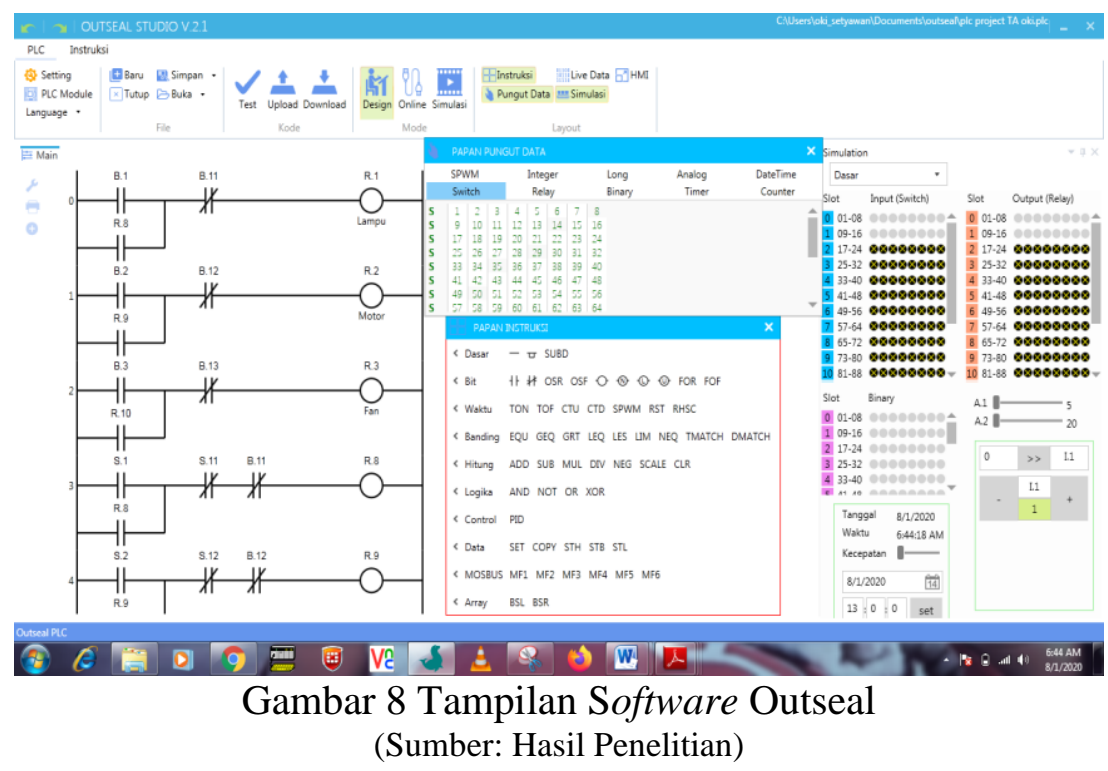

Dengan menggunakan aplikasi HMI Modbus, smartphone dapat melakukan pemantauan dan kontroling dengan desain seperti device HMI. Gambar 8 adalah block diagram pembuatan program pada HMI Modbus Android:

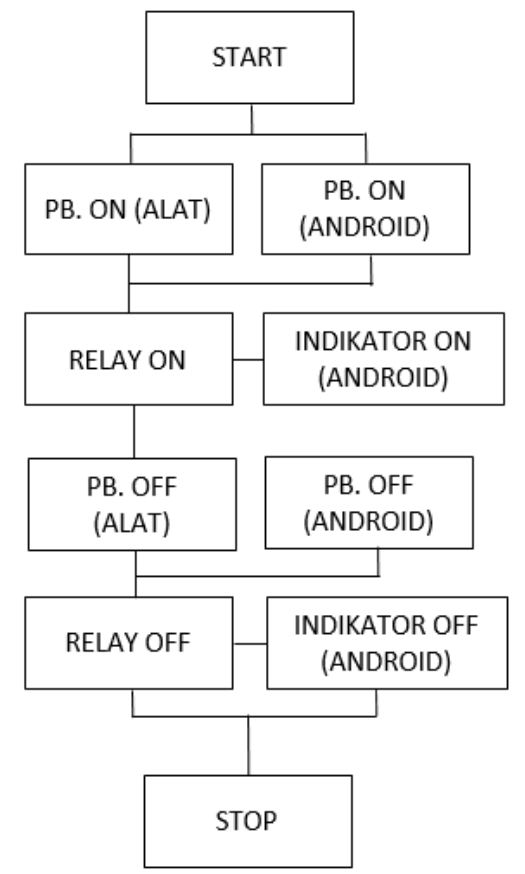

Gambar 9. Blok Diagram Alur Kerja Software HMI Modbus

Blok diagram Gambar 9, memiliki fungsi yang sama dengan dengan blok diagram pada program Outseal Studio, dikarenakan pada HMI Android dibuat program sesuai dengan intruksi-intruksi pada program Outseal Studio. 


\section{HASIL DAN PEMBAHASAN}

Pada pengujian fungsi dari komponen pada alat (Gambar 9), semua komponen dapat berfungsi dengan baik sesuai dengan wiring diagram pada desain alat. Dari 10 kali pengujian didapatkan hasil semua komponen berfungsi 100\% dan disajikan dengan Tabel 2.

Tabel 2. Hasil Modul Perangkat

\begin{tabular}{|r|l|c|c|c|c|c|c|c|c|c|c|c|}
\hline \multirow{2}{*}{ No. Perangkat } & \multicolumn{10}{|c|}{} & \multicolumn{10}{|c|}{ Pengujian ke- } & \multirow{2}{*}{ Persentase } \\
\cline { 2 - 11 } & 1 & 2 & 3 & 4 & 5 & 6 & 7 & 8 & 9 & 10 & \\
\hline 1 & Push Button Lampu Hijau & $\sqrt{ }$ & $\sqrt{ }$ & $\sqrt{ }$ & $\sqrt{ }$ & $\sqrt{ }$ & $\sqrt{ }$ & $\sqrt{ }$ & $\sqrt{ }$ & $\sqrt{ }$ & $\sqrt{ }$ & $100 \%$ \\
\hline 2 & Push Button Lampu Merah & $\sqrt{ }$ & $\sqrt{ }$ & $\sqrt{ }$ & $\sqrt{ }$ & $\sqrt{ }$ & $\sqrt{ }$ & $\sqrt{ }$ & $\sqrt{ }$ & $\sqrt{ }$ & $\sqrt{ }$ & $100 \%$ \\
\hline 3 & Push Button Fan Hijau & $\sqrt{ }$ & $\sqrt{ }$ & $\sqrt{ }$ & $\sqrt{ }$ & $\sqrt{ }$ & $\sqrt{ }$ & $\sqrt{ }$ & $\sqrt{ }$ & $\sqrt{ }$ & $\sqrt{ }$ & $100 \%$ \\
\hline 4 & Push Button Fan Merah & $\sqrt{ }$ & $\sqrt{ }$ & $\sqrt{ }$ & $\sqrt{ }$ & $\sqrt{ }$ & $\sqrt{ }$ & $\sqrt{ }$ & $\sqrt{ }$ & $\sqrt{ }$ & $\sqrt{ }$ & $100 \%$ \\
\hline 5 & Push Button Motor Hijau & $\sqrt{ }$ & $\sqrt{ }$ & $\sqrt{ }$ & $\sqrt{ }$ & $\sqrt{ }$ & $\sqrt{ }$ & $\sqrt{ }$ & $\sqrt{ }$ & $\sqrt{ }$ & $\sqrt{ }$ & $100 \%$ \\
\hline 6 & Push Button Motor Merah & $\sqrt{ }$ & $\sqrt{ }$ & $\sqrt{ }$ & $\sqrt{ }$ & $\sqrt{ }$ & $\sqrt{ }$ & $\sqrt{ }$ & $\sqrt{ }$ & $\sqrt{ }$ & $\sqrt{ }$ & $100 \%$ \\
\hline 7 & Lampu On & $\sqrt{ }$ & $\sqrt{ }$ & $\sqrt{ }$ & $\sqrt{ }$ & $\sqrt{ }$ & $\sqrt{ }$ & $\sqrt{ }$ & $\sqrt{ }$ & $\sqrt{ }$ & $\sqrt{ }$ & $100 \%$ \\
\hline 8 & Lampu Off & $\sqrt{ }$ & $\sqrt{ }$ & $\sqrt{ }$ & $\sqrt{ }$ & $\sqrt{ }$ & $\sqrt{ }$ & $\sqrt{ }$ & $\sqrt{ }$ & $\sqrt{ }$ & $\sqrt{ }$ & $100 \%$ \\
\hline 9 & Fan On & $\sqrt{ }$ & $\sqrt{ }$ & $\sqrt{ }$ & $\sqrt{ }$ & $\sqrt{ }$ & $\sqrt{ }$ & $\sqrt{ }$ & $\sqrt{ }$ & $\sqrt{ }$ & $\sqrt{ }$ & $100 \%$ \\
\hline 10 & Fan Off & $\sqrt{ }$ & $\sqrt{ }$ & $\sqrt{ }$ & $\sqrt{ }$ & $\sqrt{ }$ & $\sqrt{ }$ & $\sqrt{ }$ & $\sqrt{ }$ & $\sqrt{ }$ & $\sqrt{ }$ & $100 \%$ \\
\hline 11 & Motor On & $\sqrt{ }$ & $\sqrt{ }$ & $\sqrt{ }$ & $\sqrt{ }$ & $\sqrt{ }$ & $\sqrt{ }$ & $\sqrt{ }$ & $\sqrt{ }$ & $\sqrt{ }$ & $\sqrt{ }$ & $100 \%$ \\
\hline 12 & Motor Off & $\sqrt{ }$ & $\sqrt{ }$ & $\sqrt{ }$ & $\sqrt{ }$ & $\sqrt{ }$ & $\sqrt{ }$ & $\sqrt{ }$ & $\sqrt{ }$ & $\sqrt{ }$ & $\sqrt{ }$ & $100 \%$ \\
\hline 13 & KWH meter & $\sqrt{ }$ & $\sqrt{ }$ & $\sqrt{ }$ & $\sqrt{ }$ & $\sqrt{ }$ & $\sqrt{ }$ & $\sqrt{ }$ & $\sqrt{ }$ & $\sqrt{ }$ & $\sqrt{ }$ & $100 \%$ \\
\hline
\end{tabular}

Setelah dilakukan pengetesan dan uji coba, maka diperoleh hasil sebagai berikut:

- Push Button berfungsi normal

- Relay on saat diberi tegangan 24 V DC

- Pilot Lamp On saat diberi tegangan $220 \mathrm{~V}$ dari relay

- Fan On saat diberi tegangan 5 V DC

- Motor On saat diberi tegangan 5 V DC

- KWH meter dapat menampilkan hasil dari penggunaan daya

Selanjutnya dilakukan pengujian untuk monitoring dan kontrol melalui aplikasi HMI Android. Dari 10 kali percobaan didapatkan hasil 100\% HMI dapat berkomunikasi dengan baik dengan perangkat Outseal dan disajikan dengan Tabel 3 berikut:

Tabel 3. Hasil Pengujian Koneksi Aplikasi HMI Android

\begin{tabular}{|r|l|c|c|c|c|c|c|c|c|c|c|c|}
\hline \multirow{2}{*}{ No. } & \multicolumn{10}{|c|}{ Perangkat } & \multicolumn{10}{|c|}{ Pengujian ke- } & \multirow{2}{*}{ Persentase } \\
\cline { 3 - 11 } & & 1 & 2 & 3 & 4 & 5 & 6 & 7 & 8 & 9 & 10 & \\
\hline 1 & Tombol Lampu On & $\sqrt{ }$ & $\sqrt{ }$ & $\sqrt{ }$ & $\sqrt{ }$ & $\sqrt{ }$ & $\sqrt{ }$ & $\sqrt{ }$ & $\sqrt{ }$ & $\sqrt{ }$ & $\sqrt{ }$ & $100 \%$ \\
\hline 2 & Tombol Lampu Off & $\sqrt{ }$ & $\sqrt{ }$ & $\sqrt{ }$ & $\sqrt{ }$ & $\sqrt{ }$ & $\sqrt{ }$ & $\sqrt{ }$ & $\sqrt{ }$ & $\sqrt{ }$ & $\sqrt{ }$ & $100 \%$ \\
\hline 3 & Tombol Fan On & $\sqrt{ }$ & $\sqrt{ }$ & $\sqrt{ }$ & $\sqrt{ }$ & $\sqrt{ }$ & $\sqrt{ }$ & $\sqrt{ }$ & $\sqrt{ }$ & $\sqrt{ }$ & $\sqrt{ }$ & $100 \%$ \\
\hline 4 & Tombol Fan Off & $\sqrt{ }$ & $\sqrt{ }$ & $\sqrt{ }$ & $\sqrt{ }$ & $\sqrt{ }$ & $\sqrt{ }$ & $\sqrt{ }$ & $\sqrt{ }$ & $\sqrt{ }$ & $\sqrt{ }$ & $100 \%$ \\
\hline 5 & Tombol Motor On & $\sqrt{ }$ & $\sqrt{ }$ & $\sqrt{ }$ & $\sqrt{ }$ & $\sqrt{ }$ & $\sqrt{ }$ & $\sqrt{ }$ & $\sqrt{ }$ & $\sqrt{ }$ & $\sqrt{ }$ & $100 \%$ \\
\hline 6 & Tombol Motor Off & $\sqrt{ }$ & $\sqrt{ }$ & $\sqrt{ }$ & $\sqrt{ }$ & $\sqrt{ }$ & $\sqrt{ }$ & $\sqrt{ }$ & $\sqrt{ }$ & $\sqrt{ }$ & $\sqrt{ }$ & $100 \%$ \\
\hline 7 & Indikator Lampu & $\sqrt{ }$ & $\sqrt{ }$ & $\sqrt{ }$ & $\sqrt{ }$ & $\sqrt{ }$ & $\sqrt{ }$ & $\sqrt{ }$ & $\sqrt{ }$ & $\sqrt{ }$ & $\sqrt{ }$ & $100 \%$ \\
\hline
\end{tabular}

Dengan data diatas, dapat ditarik kesimpulan sebagai berikut:

- Tombol on pada HMI ditekan, Output lampu, fan dan motor dapat berfungsi

- Tombol off pada HMI ditekan, Output lampu, fan dan motor dapat berhenti berfungsi. 
- Tampilan indikator pada smartphone sesuai dengan kondisi On atau Off pada perangkat ketika dihubungkan
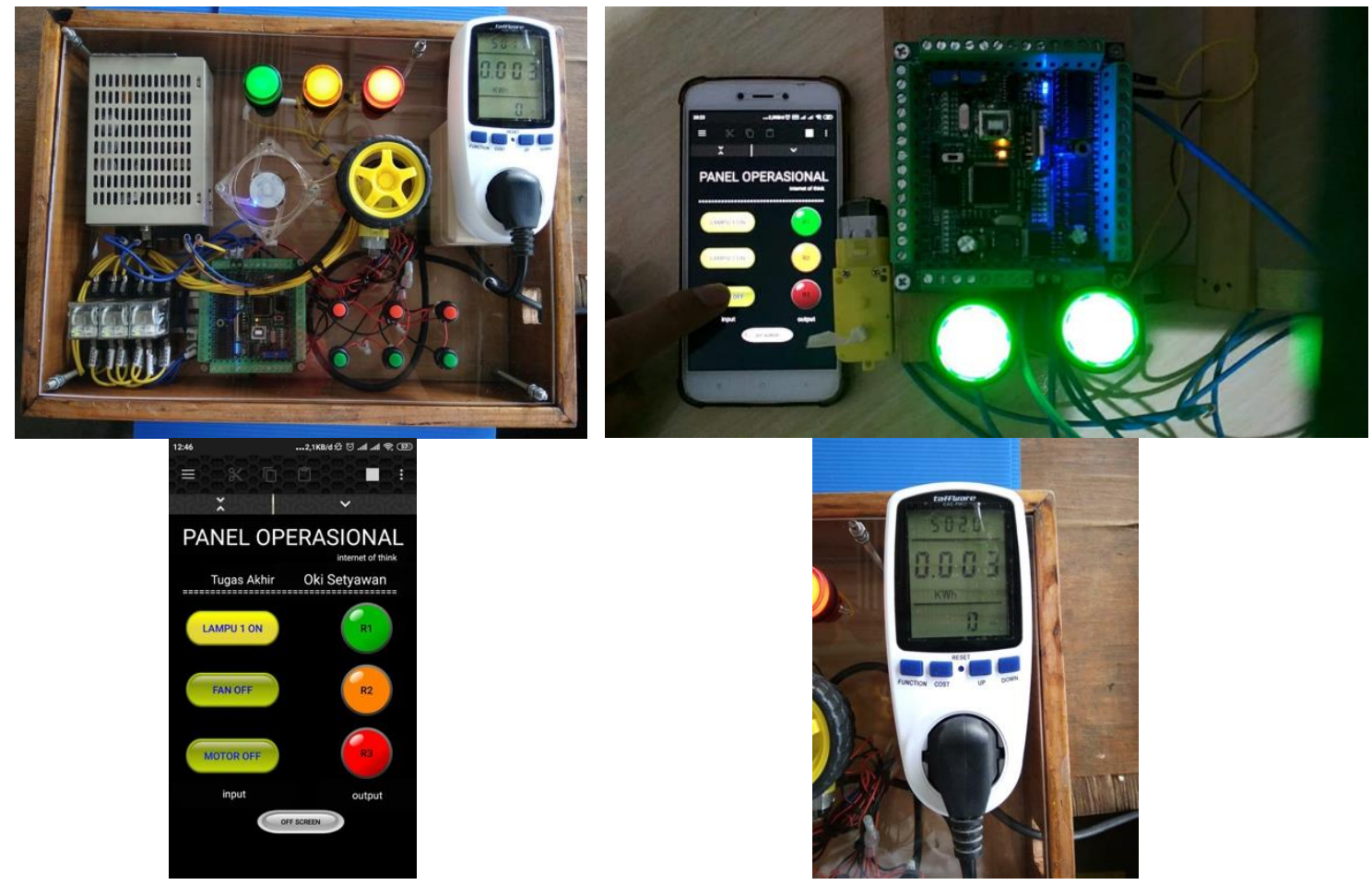

Gambar 10. Proses Pengujian HMI Dengan Outseal

Berikut pada Gambar 11 adalah grafik untuk pengujian jarak sinyal WiFi:

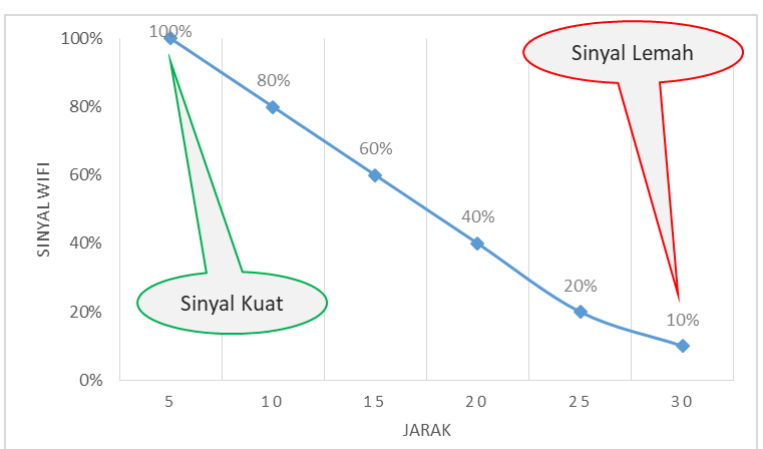

Gambar 10. Grafik Radius Terhadap Tingkat Sinyal

Dari grafik diatas dapat dilihat perbandingan jarak efektif untuk pengoperasian alat. Semakin jauh dari modul pada alat, maka sinyal yang ditangkap oleh Smartphone akan semakin kecil. Dapat disimpulkan untuk radius paling efektif penggunaan alat ini adalah pada area kurang dari 30 meter. Hal ini dapat berkaitan dengan hanya pada area tersebut yang dapat melakukan kontrol dan pemantauan. Untuk pemakaian daya dapat dilihat pada KWH meter, semakin banyak output yang digunakan, maka semakin besar pula pemakaian daya yang ditampilkan. 


\section{KESIMPULAN}

Dengan data di atas dapat disimpulkan bahwa suatu perangkat elektronik dapat dipantau dan dikontrol melalui panel operasional internal dan dapat melalui smartphone yang bertindak sebagai HMI. Komunikasi yang digunakan dapat melalui jaringan WiFi secara langsung terhadap perangkat dengan menggunakan modul sebagai pemancar sinyal. Perangkat sudah diuji coba dengan keberhasilan $100 \%$ pada fungsi seluruh panel yang dirakit. Aktual pemakaian daya juga dapat dilihat melalui perangkat KWH meter yang sudah dipasang pada alat. Semakin lama dan semakin banyak Output yang On, maka semakin besar pula daya yang digunakan. Pemantauan dan kontrol peralatan melalui jaringan internet dengan menggunakan smartphone atau android sebagai HMI. Untuk radius paling efektif penggunaan alat ini adalah pada area kurang dari 30 meter.

\section{UCAPAN TERIMAKASIH}

Penulis mengucapkan terima kasih kepada Tim di Laboratorium Teknik Elektro Universitas Jayabaya yang telah memberikan fasilitas dan dukungan dalam proses penelitian ini.

\section{DAFTAR PUSTAKA}

[1] T. D. Hendrawati, Y. D. Wicaksono and E. Andika, "Internet of Things: Sistem KontrolMonitoring Daya Perangkat Elektronika Program Studi Teknik Komputer," JTERA (Jurnal Teknologi Rekayasa) 3(2):177, vol. 3, no. 2, p. 177, 2018.

[2] D. Prihatmoko, "Perancangan Sistem Monitoring Perangkat Elektronik Rumah Menggunakan Internet," Jurnal Simetris, vol. 9, no. 1, pp. 279-286, 2018.

[3] D. Yuhendri, "Penggunaan PLC Sebagai Pengontrol Peralatan Building Automatis," JET (Journal of Electrical Technology), vol. 3, no. 3, pp. 121-127, 2018.

[4] R. Mubarroq, "Rancang Bangun Sistem Kendali Otomatis Silo Dengan Metode Sortasi Berdasarkan Jenis Kemasan Produk Menggunakan HMI-PLC," Universitas Teknologi Yogyakarta, Yogyakarta, 2019.

[5] A. Bakhtiar, Buku Panduan Dasar Outseal PLC, Outseal, 2020.

[6] A. Bakhtiar, Wiring Outseal V1, Outseal, 2020.

[7] Sagram, "HMI Modbus User Guide EN 1.18," 2016. [Online]. Available: sagram.net.

[8] D. U. Suwarno, "Modbus HMI bluetooth for outseal PLC," in AIP Conference Proceedings 2217, Surakarta, 2019.

[9] Shenzhen Doctors of Intelligence \& Technology Co., Ltd, User Manual for TTL-WiFi, Shenzhen Doctors of Intelligence \& Technology Co., Ltd, 2017.

[10] A. Bakhtiar, Wiring Diagram Outseal PLC Mega128 V1, Outseal, 2020.

[11] A. Susanto, "Modul Programmable Logic Controller (PLC) Berbasis Arduino Severino," Jurnal Edukasi Elektro, vol. 1, no. 2, 2017.

[12] I. Chaerunnisa, S. B. Mulia and M. Eriyadi, "Aplikasi PLC Pada Alat Pengisian Air Minum Otomatis," Jurnal Elektra, vol. 3, no. 2, pp. 61-68, 2018. 
[13] Risfendra, Sukardi and H. Setyawan, "Uji Kelayakan Penerapan Trainer Programmable Logic Controller Berbasis Outseal PLC Shield Pada Mata Pelajaran Instalasi Motor Listrik," Jurnal Teknik Elektro dan Vokasional, vol. 6, no. 2, pp. 48-53, 2020.

[14] T. A. Santosa, "Rancang Bangun Automatic Transfer Switch (ATS) Berbasis Outseal PLC," Universitas Muhammadyah Palembang, Palembang, 2019.

[15] S. A. Qatrunnada, Y. Oktarina, T. Dewi, Evelina and P. Risma, "Sistem Kendali Pengisian Jus Otomatis Menggunakan Sensor Infrared dan Waterflow Berbasis PLC," Journal of Applied Smart Electrical Network and Systems, vol. 1, no. 1, pp. 1-5, 2020. 